\title{
Functional and cognitive profile of elderly residents in a long-term care institution in the northeast
}

\author{
Adryanne Almeida Santos ${ }^{(1)}$, Ana Lídia Santos Barros da Silva ${ }^{(1)}$, Felipe Arllan Bezerra Santos ${ }^{(1)}$, \\ Juliana Eletícia Silva Barbosa ${ }^{(1)}$, Laize Pacheco Dos Santos Almeida ${ }^{(1)}$, Renata de Sousa Mota ${ }^{(2)}$, Alan Carlos Nery dos Santos ${ }^{(1)}$
}

\begin{abstract}
Background: Aging is a physiological process characterized as the beginning of a stage of life in which happen social, physical and psychological changes. Among these, cognitive and functional decline has been one of the most frequent, and may be enhanced by the process of institutionalization. Objectives: The aim of this study was to describe the cognitive and functional profile of elderly residents in a Long-Term Care Institution for the Elderly (LTCI). Methods: A cross-sectional descriptive study whose population was composed of elderly people of both genders, residents in the "Associação Feirense de Assistência Social" in Feira de Santana (BA), Brazil. The elderly with physical and mental limitations that made it impossible to perform the functional and cognitive tests were excluded from the study. The survey was completed in December 2017. The Barthel Index, Katz Index, Berg Balance Scale (BERG) and Timed Up and Go (TUG) were used for functional evaluation. The first two tools were used to classify functional independence in the activities of daily living (ADL's), and the others to categorize risk of fall. It was used the Mini-Mental State Exam to evaluate cognition. In addition, a form was created to collect clinical and sociodemographic variables. The results of this study were described in percentage. Results: From the 35 elderly residents, 25 were included, of which 15 were female, with ages between 62 and 95 years. Regarding Education, $60 \%$ are illiterate, $32 \%$ have 1 to 4 years, $4 \%$ have 5 to 8 years and $4 \%$ have 9 to 11 years of studies. $92 \%$ of the population presented cognitive alterations. Regarding functionality, $66.6 \%$ of the elderly had a dependent gait, with $56.2 \%$ of females. In the assessment of the risk of falling, $60 \%$ presented moderate risk by TUG and $82.6 \%$ presented a high risk by the Berg scale. Considering the Barthel index and the Katz index, 52\% had dependence on ADLs. 96\% did not practice physical activity and $62.5 \%$ did not undergo Physical Therapy. The most frequent comorbidities were arterial hypertension (64.3\%) and diabetes mellitus (36\%). Conclusion: The results of this study indicate that the studied population presents cognitive alterations, gait dependent, greater probability for risk of falls, low level of education and physical activity, besides longevity, which may suggest that the institutionalization process brings negative repercussions for these subjects.

Keywords: Aging; Institutionalization; Geriatric Evaluation; Health of the Elderly.
\end{abstract}

\section{INTRODUCTION}

Aging can be understood as a natural process and a progressive decrease in the functional reserve of subjects, which may lead to changes in some health indicators, for example, the functionality, cognition and psychic function. These changes resulting from this process bring to the subject a limitation in the accomplishment of the activities of daily life, requiring special care of the family and caregivers ${ }^{(1,2)}$. According to $\mathrm{WHO}^{(3)}$, by 2025 Brazil will be the sixth largest country in the world in the number of the elderly and by 2050 this population over 60 years will increase from 846 million to 2 billion people, making chronic diseases and the welfare of the elderly a new challenge for public health policies. Among the changes observed in this process, cognitive and functional decline has been one of the most present. It is progressive with the advancing age, and can increase by about $5 \%$ in the age group of 60 years and up to $50 \%$ among subjects aged 90 years or more ${ }^{(1)}$. From this, it is observed that the central nervous system is the most impaired, limiting the intellectual abilities, such as: cognition, speech, reasoning and notion of space; and these factors may also influence the family members to look for Long-Term Care Institutions for the Elderly $\left(\right.$ LTCI) ${ }^{(4,5)}$.

The LTCI is designed so that the elderly live fully, in collective habilitation, enjoying clothing, food and medicines, as well as leisure activities and practices of interdisciplinary actions. Most are of philanthropic origin (62.2\%), being only $6.6 \%$ governmental principle, and supported by donations and by the benefit of the institutionalized ones ${ }^{(6)}$. In addition, they are shown as monotonous places and do not allow the

Study developed in the "Health Sciences in Physiotherapy Research Group" from the Universidade Salvador (UNIFACS), Feira de Santana, BA, Brazil.

Corresponding Author: Alan Carlos Nery dos Santos. Universidade Salvador (UNIFACS), Campus Getúlio Vargas, Feira de Santana, BA, Brazil. Address: Av. Getúlio Vargas, 2.734 - Parque Getúlio Vargas, Feira de Santana - BA, Brazil. CEP: 44075-525. E-mail: carlos.nery@unifacs.br

${ }^{(1)}$ Health Sciences in Physiotherapy Research Group. Universidade Salvador (UNIFACS), Feira de Santana, BA, Brazil.

Full list of author information is available at the end of the article.

Financial support: The authors declare that there was no financial support.

Submission date January 01, 2019; Acceptance date February 13, 2019; Publication date March 132019 
elderly to perform activities that allow new experiences from the contact with other residents, as well as the valuing of old experiences and acquired skills, which presupposes aging as a stage that development or learning no longer occurs ${ }^{(7)}$.

In this way, the presence of debilitated elderly, totally dependent, with severe cognitive impairment is more prevalent in the context of $\mathrm{LTCl}^{(2)}$. The institutionalization of these subjects can represent a new stage of life, which can put them in a situation of social isolation, compromising their autonomy and independence, significantly reflecting on their quality of life ${ }^{(7)}$. Based on the aforementioned referential, the main objective of this study was to describe the cognitive and functional profile of a group of elderly living in a long-term care institution.

\section{METHODS}

It is a cross-sectional study to describe the cognitive and functional profile of elderly living in the "Associação Feirense de Assistência Social" (AFAS) located in city of Feira de Santana, BA, Brazil. This research began after the approval of the Ethics Committee of the Universidade Salvador with number 2.322.388 and CAAE 70218717.4.0000.5033 and authorization of the technical responsible of the Institution. The population was invited to participate in the study and informed by the team of researchers about the possible risks and benefits, and signed the Informed Consent Form. Data collection began in October 2017 and ended in November 2017. The elderly population of the institution was 49 elderlies of both genders, aged between 62 and 95 years, all residing in the AFAS. The inclusion criteria used were: subjects over 60 years of age according to Instituto Brasileiro de Geografia e Estatística (IBGE) criteria; accept to participate in the survey; be resident for at least 1 year. Subjects with advanced neurodegenerative diseases that severely affected their verbal, motor and cognitive function, those with limitations that made the tests unviable, and the elderly who became residents at the institution after the beginning of the collection, were excluded from the study.

To characterize the epidemiological profile of the elderly it was applied a clinical file composed of sociodemographic and clinical variables, contemplating the following information: name, number, gender, age, institutionalization time, education level, marital status, place of birth, pathologies, use of auxiliary devices, history of fall and life habits and comorbidities. Data collection was performed with the following steps:

Cognitive assessment was performed through the Mini-Mental State Exam (MMSE). This instrument is a brief test that presents a questionnaire of 30 points, aiming to evaluate superficially the cognitive functions and dementia. The test has the durability of 10 minutes and does not require specific material, aiming to evaluate several domains, such as: spatial and temporal orientation, immediate memory and recall, calculation, language, repetition, comprehension, writing and drawing copy. It should be used as a tracking tool, not replacing a more detailed evaluation, because, despite evaluating several domains, it is one of the few tests validated and adapted for the Brazilian population. In this way, to be classified with the preserved cognitive, the following cutoff points were used: illiterates must obtain in the test a score equal to or higher than 19 points, subjects with 1 to 4 years of study a score equal or superior to 23 points and for the others the score must be equal to or greater than 24 points ${ }^{(1)}$. To assess the risk of falls, it was used the Timed Up and Go test (TUG) and the Berg Balance Scale (BBS). According to the World Health Organization, falls are commonly defined as "an event which results in a person coming to rest inadvertently on the ground or floor or other lower level", excluding intentional position changes to lean on furniture, walls, or other objects. In this way, the first test is based on evaluating the speed of execution in raising of a chair with arms, to walk three meters ahead, to turn, to walk back and to sit in the chair again. A digital chronometer was used to perform this test and marking three meters of the route of the evaluated. With this test is possible to classify the performance of patients correlating with muscular strength of the lower limbs, balance and ease of walking, thereby tracing the risk of falls. The test is considered normal when the individual can perform in less than 10 seconds, between 10 and 19 seconds is considered a moderate risk of falling, and greater than 20 seconds is considered a high risk of falls. Regarding the BBS, it is characterized as an instrument comprising a scale of 14 daily tasks involving static and dynamic balance, such as reaching, rotating, transferring, standing, and getting up. The lower the score the greater the problem, that is, a score lower than 19 indicates a five times higher risk of falls ${ }^{(1)}$. The analyzed items include the ability of the subject to maintain positions of increasing difficulty in different situations of the day. The Barthel Index and the Katz Index were used to evaluate functional independence of the patient in some activities of daily living, such as: eating, personal hygiene, dressing, continence and transfers. The first tool has a score of zero, five, ten and fifteen; the score is proportional to independence, the higher the score the more independent the elderly. The Katz index has a score of zero to six points, which can characterize the participant as totally dependent (perform less than two activities), partially dependent (three activities) and fully independent (more than three activities). In general, the mean evaluation time of each subject lasted 30 minutes. The results were tabulated through the Statistical Package for the Social Science (SPSS), version 20.0, in which the analysis was performed by percentage and absolute frequency.

\section{RESULTS}

From the total of 49 elderlies, 25 met the inclusion criteria and were included in the study, in which $60 \%$ are female, with age between 62 and 95 years $(79 \pm 10.06)$ and mean institutionalization time greater than 90.6 months \pm 84.5 . 
Among the clinical and sociodemographic variables presented in Table 1, it is noticed that: with respect to the educational level, $60 \%$ are illiterate, $32 \%$ have 1 to 4 years of studies, $4 \%$ have 5 to 8 years and $4 \%$ have 9 to 11 years; $96 \%$ did not practice physical activity, $62.5 \%$ did not undergo Physical Therapy, $64,3 \%$ with hypertension and $36 \%$ diabetes mellitus. In addition, $68 \%$ reported more frequent pain in regions such as the spine and knee, and $40 \%$ had a history of falls in the institution. Of these, $30 \%$ reported that the cause of the fall was malaise, $20 \%$ for weakness and $50 \%$ for other reasons. Regarding pharmacological treatment, all the elderly reported

Table 1 - Sociodemographic and clinical characteristics of institutionalized elderly.

\begin{tabular}{|c|c|}
\hline & $\mathrm{n} \%$ \\
\hline \multicolumn{2}{|l|}{ GENDER } \\
\hline Female & $1560 \%$ \\
\hline Male & $1040 \%$ \\
\hline \multicolumn{2}{|l|}{ LITERACY } \\
\hline Illiterate & $1456 \%$ \\
\hline 1 to 4 years of education & $832 \%$ \\
\hline 5 to 11 years of education & $28 \%$ \\
\hline \multicolumn{2}{|l|}{ PAIN } \\
\hline Yes & $1768 \%$ \\
\hline No & $832 \%$ \\
\hline \multicolumn{2}{|l|}{ PHYSICAL ACTIVITY } \\
\hline Non-practitioner & $2496 \%$ \\
\hline Practitioner & $14 \%$ \\
\hline \multicolumn{2}{|l|}{ GAIT } \\
\hline Dependent & $1768 \%$ \\
\hline Independent & $832 \%$ \\
\hline Auxiliary device (Walking stick, Crutch and Walker). & $936 \%$ \\
\hline \multicolumn{2}{|l|}{ HISTORY OF FALLS } \\
\hline Yes & $1040 \%$ \\
\hline Malaise & $330 \%$ \\
\hline Weakness & $220 \%$ \\
\hline Other reasons & $550 \%$ \\
\hline No & $1560 \%$ \\
\hline \multicolumn{2}{|l|}{ COMORBITIES } \\
\hline Hypertension & $1664 \%$ \\
\hline Diabetes & $936 \%$ \\
\hline \multicolumn{2}{|l|}{ CONTINUOUS USE OF MEDICINES } \\
\hline Yes & $25100 \%$ \\
\hline \multicolumn{2}{|l|}{ No } \\
\hline \multicolumn{2}{|l|}{ PHYSIOTHERAPEUTIC TREATMENT } \\
\hline No & $1560 \%$ \\
\hline Yes & $1040 \%$ \\
\hline
\end{tabular}

that they use continuous medication with an average of 2 to 3 medications per elderly. In the functional evaluation, presented in table $2,66.6 \%$ of the elderly had a dependent gait, with $56.2 \%$ of females. In the assessment of the risk of falling, $60 \%$ presented moderate risk by TUG and $82.6 \%$ presented a high risk by the BBS. Besides that, $52 \%$ had dependence on ADLs. On the other hand, in the cognitive evaluation described in table $3,92 \%$ of the population presented cognitive alteration with an average score of 15.7 points which could mean a poor performance on the test.

\section{DISCUSSION}

This study aimed at describing the cognitive and functional profile of the elderly from a long-term care institution, and identified that the population evaluated has a high probability of risk of fall, ADL's and gait dependence, and cognitive deficit. These changes were more frequent in the female population. These results corroborate with the study of Fhon et al. ${ }^{(8)}$, that evaluated the fragility syndrome among institutionalized elders through the Functional Independence Measure (FIM), Lawton-Brody Instrumental Activities of Daily Living Scale (IADL) and Edmonton Frail Scale (EFS). The authors demonstrated a higher prevalence of fragility and dependence

Table 2 - Cognitive and functional characteristics of institutionalized elderly.

\begin{tabular}{lr}
\hline & $\mathrm{n} \%$ \\
\hline MMSE & $2392 \%$ \\
Cognitive Alteration & \\
TUG & $360 \%$ \\
Moderate risk & $240 \%$ \\
High risk & \\
BERG SCALE & $28,6 \%$ \\
Moderate risk & $1982,6 \%$ \\
High risk & \\
THE BARTHEL AND THE KATZ INDEX & $1352 \%$ \\
Dependent & $1248 \%$ \\
Independent & \\
\hline Note: MMSE: Mini-Mental State Exam; TUG: Time-Up and Go test.
\end{tabular}

Table 3 - Mini-Mental State Exam Score.

\begin{tabular}{lc}
\hline \multicolumn{1}{c}{ Mini-Mental State Exam } & Score (Mean \pm SD) \\
\hline Orientation (0-10 points) & $5.7 \pm 2.9$ \\
Registration (0-3 points) & $2.3 \pm 1.0$ \\
Attention (0-5 points) & $0.6 \pm 1.3$ \\
Recall (0-3 points) & $1.1 \pm 1.1$ \\
Language (0-9 points) & $5.7 \pm 1.7$ \\
Final Score (0-30 points) & $15.7 \pm 5.1$ \\
\hline
\end{tabular}


for the performance of ADL's in female population ${ }^{(8)}$. The higher prevalence of cognitive and functional changes in the female population may be partially justified by IBGE data indicating that women live on average 7.2 years longer than men. However, despite the greater longevity, these women experience a higher rate of decline in health ${ }^{(9)}$. In addition, the population of present study had a $60 \%$ risk of falling from the TUG and $82 \%$ from the BBS. Supporting this result, WHO data suggest that falls are important public health problems and are responsible for $40 \%$ of all injury-related deaths in the elderly population. In addition, $28 \%$ to $35 \%$ of people over 65 years of age suffer falls each year (2-4), with more than $50 \%$ being hospitalized with injuries. According to the studies, the frequency of falls increases with age and the level of fragility. In addition, it has been demonstrated that elderly people living in nursing homes fall more frequently than those living in the community ${ }^{(10)}$.

The main underlying causes of all admissions to hospital are related to falls: hip fracture, traumatic brain injuries and injuries of the upper limbs. In the present study, the most prevalent complaint in the context of falls was due to malaise $(30 \%)$, muscle weakness (20\%) and irregularities found the area (20\%). In parallel to this, it has been documented a high frequency of sedentary elderly in the $\mathrm{LTCl}^{\prime} \mathrm{S}^{(11)}$ and $93 \%$ of the participants of this study reported that they did not practice any type of physical activity. Similar data were reported by Fochat et al. ${ }^{(12)}$, in which $43.4 \%$ of the elderly did not perform physical activity, and $27.9 \%$ performed at frequencies below the global recommendations. The $\mathrm{WHO}^{(13)}$ recommends 150 minutes of mild or moderate physical activity per week (about 20 minutes per day) or at least 75 minutes of more intense physical activity per week. Therefore, regular physical activity is considered essential for the maintenance of physical fitness, decrease in muscle mass loss, balance gain, resistance, muscle strength and consequent preservation of functional independence in this population ${ }^{(12,14)}$. On the other hand, in the present study, $52 \%$ of the population presented dependence for ADL's and $66.6 \%$ of them were dependent, which indicates limitations in the functionality of the evaluated subjects. Such a limitation can cause loss of independence in basic life activities, changes in gait and imbalance, remaining in constant reduction in both genders ${ }^{(14-17)}$. Fhon, et al. ${ }^{(8)}$, with evaluation instruments similar to those applied in this study, observed a greater dependence for ADL's and also observed that the more comorbidities, the greater the level of dependence of this population. Besides that, Giaquini et al.(18), in 2017, assessed the difficulty of locomotion in the institutionalized elderly in a sample of 191 subjects. They identified that the majority of the population needed help to walk and it may be associated with the decreased strength and muscle mass, the polypharmacology of the elderly, and diseases that affect the nervous system. Consequently, this increases the risk of accidents, as well as progress to bed restriction.
In addition, when comparing groups of elderly living in LTCI's to non-institutionalized elderly, the first ones presented greater difficulty in locomotion ${ }^{(18-20)}$

During aging, the elderly begin to present dysfunctions in the locomotor system and sensory system, in this way, they begin to adopt compensatory mechanisms to maintain adequate posture and functional gait, such as: diminution of the dissociation of waist, enlargement of the support base, reduction of the time in the balance phase, reduction of the length and height of the step and the reduction of the speed of the march. These changes may reduce the independent movement of the subject and the ability to perform their ADLs because of the fear of falling ${ }^{(21,22)}$. In some advanced cases of decline, the trunk balance is also impaired. With this difficulty trunk control, the elderly will adopt the posture in trunk flexion and lean sideways to a side. This adopted posture makes it difficult to interact with the social environment, to eat due to neck flexion and anterior head, to hygiene and may favor bronchial aspiration of food content ${ }^{(23)}$. In addition to the results cited above, our population had a high illiteracy rate and low MMSE score. This result seems to be linked to the historical process, mainly due to the difficulty of accessing schools in the past. At that time, women faced greater difficulty in entering school because of the typical culture of difference of genders ${ }^{(4)}$.

According to Zimmermmann et al. ${ }^{(24)}$, the percentage of elderly with cognitive impairment (67\%) in the LTCIs is worrying. Institutionalized elderly with lower cognitive performance have a considerable impairment in functional abilities, especially in their ADLs ${ }^{(25)}$. However, this decline may be related not only to the level of education, but also to the time of institutionalization of these elderly, which could be verified in this study. Elderlies with greater time of institutionalization had lower scores on the Mini-Mental State Exam, which characterizes cognitive impairment ${ }^{(2,26)}$. In addition, this functional cognitive decline can be influenced by several factors and mechanisms, for example disuse, inactivity, low motor performance and diseases such as depression. In addition to these changes, behavioral factors such as abusive alcohol consumption and poly drug use also stand out as a mechanism for cognitive decline. Finally, psychological factors such as lack of motivation, and genetic and social factors such as loneliness and isolation, may be more striking than aging itself to promote structural and functional modifications of the nervous system, as well as their functions ${ }^{(27)}$. Mello et al. (27), also points out that regardless of the factors cited above, cognitive decline during aging mainly affects memory and learning, making it necessary stimulation practices to enable independence and quality of life. According to the World Health Organization, loneliness, social isolation, lack of familiarity, low education, abuse and exposure to conflict, greatly increase the risk of disability and premature death of the elderly. It should be noted that most of these subjects are institutionalized in opposition to their will, and more than that, 
the family separation can help to depress the emotional state of them. Several authors reports the relevance of the family to the life of these subjects, and it is indispensable that the people of social and familiar life approach and give affection and support ${ }^{(27-30)}$

Finally, the present study has some limitations that need to be discussed. Among them, it is highlighted the fact that it is a cross-sectional study, a methodology that limits the presentation of home-effect relationships, the fact that we used only one long-term care institution, which may not adequately represent the researched population, and the absence of a control group for a better understanding of the outcomes analyzed by the present study. On the other hand, this study has strengths, such as the analysis of cognitive and functional variables, which besides indicating cognitive and functional decline, allows us to stratify the risk of falling, and thus adopt strategies to prevent them. In addition, our results adequately represent the individual characteristics of an institution, which is not always represented in the literature in general.

\section{CONCLUSION}

The results of this study indicate that the studied population presents cognitive alterations, gait dependent, greater probability for risk of falls, low level of education and physical activity, besides longevity. These results may suggest that the process of institutionalization has negative repercussions for these subjects, a fact that suggests to the creation and adoption of public policies aimed at the health of the elderly. In addition, it points out the need for family and social participation in long-term care institutions in order to minimize cognitive and functional complications for this population.

\section{AUTHORS' CONTRIBUTION}

Research design: Mota RS, Santos FAB, Santos AA, Silva ALSB and Santos ACN; Data collection: Mota RS, Santos FAB, Santos AA, Silva ALSB, Barbosa JES and Almeida LPS; Data analysis and interpretation, and Writing of the manuscript: Mota RS, Santos FAB, Santos AA, Silva ALSB and Santos ACN; Critical review of the manuscript: Mota RS, Barbosa JES, Almeida LPS and Santos ACN.

\section{CONFLICTS OF INTERESTS}

The authors declare that there was no conflict of interests.

\section{AUTHORS DETAILS}

(2) Universidade Federal do Recôncavo da Bahia (UFRB), Feira de Santana, BA, Brazil.

\section{REFERENCES}

1. Ministério da Saúde. Envelhecimento e saúde da pessoa idosa. Caderno de Atenção Básica. 2006.

2. Melo BRS, Diniz MAA, Casemiro FG, Figueiredo LC, Orlandi AAS, Haas VJ, et al. Avaliação cognitiva e funcional de idosos usuários do serviço público de saúde. Esc Anna Nery. 2017; 21(4):e20160388
3. Mundo terá 2 bilhões de idosos em 2050 [internet]. ONU BR. 2014 [atualizado em 11 de novembro de 2014]. Acesso em: Disponivel em: https://nacoesunidas.org/mundo-tera-2-bilhoes-de-idosos-em-2050oms-diz-que-envelhecer-bem-deve-ser-prioridade-global/

4. Lisboa CR, Chianca TCM. Perfil epidemiológico, clínico e de independência funcional de uma população idosa institucionalizada. Rev Bras Enferm. 2012. 65(3): 482-7.

5. Converso MER, Lartelli I. Caracterização e analise do estado mental e funcional de idosos institucionalizados em instituições públicas de longa permanência. J Bras Psiquiatr. 2007. 56(4): 267-272.

6. Camarano AA, Kanso S. As instituições de longa permanência no Brasil. R bras Est Pop. 2010. 27(1):233-235.

7. Alves-Silva, J. D., Scorsolini-Comin, F. \& Santos, M. A. Idosos em Instituições de Longa Permanência: Desenvolvimento, Condições de Vida e Saúde. Psicologia: Refl exão e Crítica. 2013. 26(4): 820-830.

8. Fhon JRS, Diniz MA, Leonardo KC, Kusumota L, Haas VJ, Rodrigues RAP. Síndrome de fragilidade relacionada à incapacidade funcional no idoso. Acta Paul Enferm. 2012. 25, 4, 589-94.

9. Mônica M. Expectativa de vida do brasileiro sobe para 75,5 anos [internet]. IBGE. 2017- [atualizada em 11 de julho de 2018]. Acesso em. Disponível em: https://agenciadenoticias.ibge.gov.br/agencia-noticias/2012agencia-de-noticias/noticias/18469-expectativa-de-vida-do-brasileirosobe-para-75-8-anos

10. Ibrahim A, Singh DKA, Shahar S. Timed Up and Go' test: Age, gender and cognitive impairment stratified normative values of older adults. Plos one. 2017. 12(10): e018564.

11. Polaro SHI, Fideralino JCT, Nunes PAO, Feitosa ES, Gonçalves LHT. Idosos residentes em instituições de longa permanência para idosos da regi/ao metropolitana de Belém-PA. Rev Bras. Geriatr Gerontol. 2012. 15(4):777784

12. Fochat RC, Horsth RBO, Vianna CLC, Raposo NRB, Vieira RCPA, Chicourel EL. Perfil sociodemográficos de idosos frágeis institucionalizados em Juiz de Fora - Minas Gerais. Rev APS. 2012. 15(2): 178-184.

13. Atividade física [internet]. Ministério da Saúde. 2017 - [atualizado em 25 de naio de 2017]. Acessado em. Disponível em: http://portalms. saude.gov.br/component/content/article/781-atividades-fisicas/40390atividade-fisica.

14. Marciel MG. Atividade física e funcionalidade do idoso. Motriz. 2010. 16(4): 1024-1032.

15. Fluetti MT, Fhon JRS, Oliveira AP, Chiquito LMO, Marques S. The frailty syndrome in institutionalized elderly persons. Rev Bras Geriat e Gerontol. 2018. 21(1):

16. Souza CC, Valmorbida LA, Oliveira JP, Borsatto AC, Lorezini M, Knorst $\mathrm{MR}$ et al. Mobilidade funcional em idosos institucionalizados e não institucionalizados. Rev Bras Geriatr Gerontol. 2013. 16(2): 285-293.

17. Mattos IE, Carmo CN, Santiago LM, Luz LL. Factors associated with functional incapacity in elders living in long stay institutions in Brazil: a cross-sectional study. BMC Geriatrics. 2014. 14:47

18. Giaquini F, Lini EV; Doring M. Prevalência de dificuldade de locomoção em idosos institucionalizados. Acta Fisiatr. 2017. 24(1):1-6.

19. Costa C, Kemer CG, Oliveira DV, Antunes MD, Júnior JRAN, Silva CCR. Mobilidade na marcha, risco de quedas e depressão em idosos institucionalizados e não institucionalizados. Rev Saúde e Pesquisa. 2017. 10(2): 293-300.

20. Casas-Herrero A, Cadore EL, Zambom-Ferrase F, Idoate F, Millor N, Martínez-Ramirez A e et al. Functional capacity, muscle fat infiltration, power output, and cognitive impairment in institutionalized frail oldest old. Rejuvenation Research. 2013. 16(5): 396-403.

21. Lojudice DC, Laprega MR, Rodrigues RAP, Júnior ALR. Quedas de idosos institucionalizados: ocorrência e fatores associados. Rev Bras Geriatr Gerontol. 2010. 13(3):403-412.

22. Bianchi AB, Oliveira JM, Bertolini SMMG. Marcha no processo de envelhecimento: alterações, avaliação e treinamento. Rev Uningá. 2015. 45: 52-55. 
23. Mendes, TAB. Geriatria e Gerontologia. 1ed. São Paulo: Manole, 2014

24. Zimmermmann IMM, Leal MCC, Zimmermmann RD, Marques APO. Idosos institucionalizados: comprometimento cognitivo e fatores associados. Geriatr Gerontol Aging. 2013. 9(3): 86-92.

25. Trindade APNT, Barboza MA, Oliveira FB, Borges APO. Repercussão do declínio cognitivo na capacidade funcional em idosos institucionalizados e não institucionalizados. Fisioter Mov. 2013. 26(2): 281-9.

26. Santiago LM, Luz LL, Silva JFS, Oliveira PH, Carmo KN, Mattos IE. Condições sociodemograficas e de saúde de idosos institucionalizados em cidades do Sudoeste e Centro-Oeste do Brasil. Geriatr Gerontol Aging. 2016. 10(2):86-92

27. Mello BLD, Haddad MCL, Dellaroza MSG. Avaliação cognitiva de idosos institucionalizados. Rev Acta Scientiarum. 2012. 34(1): 95-102.
28. Silva AO, Pereira APM, Gonçalves RD, Vieira AS, Medeiros RF, Altermann CDC. Perfil cognitivo de idosos institucionalizados de Uruguaiana/RS. Rev contexto e saúde. 2011. 10(20): 1185-1190.

29. Gonçalves D, Altermann C, Vieira A, Machado AP, Fernandes R, Oliveira A e et al. Avaliação das funções cognitivas, qualidade de sono, tempo de reação e risco de quedas em idosos institucionalizados. Est interdiscipl envelhec. 2014. 10(1):95-108.]

30. Camargo-Hernández KC, Laguado-Jaimes E. Grado de deterioro cognitivo de los adultos mayores institucionalizados en dos hogares para ancianos del área metropolitana de Bucaramanga - Santander, Colombia. Rev Univ. Salud. 2017. 19(2):163-170. 